\title{
A CONTRASTIVE ANALYSIS BETWEEN ENGLISH AND INDONESIAN KINDS OF SENTENCES
}

\author{
Lulu Jola Uktolseja, lulujola39@gmail.com, Universitas Victory Sorong, Indonesia \\ Hamim Sujaja, hamimfsh@gmail.com, Universitas Victory Sorong, Indonesia \\ Mario Matinahoru, mariofmatinahoru@gmail.com, Universitas Victory Sorong, Indonesia
}

\begin{abstract}
The difference between English and Indonesian language becomes one of the hardest things to learn and to be understood. It could be seen from the grammar of the language and the system of communication between both languages. The aim of this study is to identify the difference and similarity of sentences between English and Indonesian language and contrastive analysis between both languages. This study used qualitative descriptive approach to find out the contrast between both languages. The sample in this study was 20 students. They were $2^{\text {nd }}$ semester students of English Department Students in Victory University. The result of this study showed that the main errors of the students were in Declarative Sentence (DS), Negative Sentence (NS), Interrogative Sentence (IS) and Exclamatory Sentence (ES). The students' errors were caused by different pattern sentences whereas the Imperative Sentence (IMS) has the same pattern with English.
\end{abstract}

Keywords: Contrastive Analysis, English and Indonesian, Kinds of Sentences

\section{INTRODUCTION}

Society uses language as a tool to communicate and interact with each other. Language plays an important role in society particularly to build social interaction during social communication. Humans cannot express their thoughts and feelings without language. We cannot imagine how life will be if the language disappears. Life will be so empty, and people will only live with themselves. Generally, all human activities are always related to language. Language is needed in all human aspects such as religion, education, occupation, business, and health. It helps people to tell their thoughts, ideas, and desires. Moreover, with language people can improve themselves in social interaction and also their career.

A language is a vocal symbol or system of arbitrary, that permits all people to communicate or to interact. Kridalaksana (1993) also said that language is a symbol system sound an arbitrary language that allows people to work together, interact and identify. It can be concluded that language is the communication tool full of meaning to unite people and help them to interact, build social interaction in their community and also help them to work together.

Each nation around the world has its own language that is their identity. Every language in the world is unique because every nation has a different language that differs into local or national languages. Thus, it will be hard for people from a different country to understand what other people talk in their own language. English appears as the international language to help interaction between different nations.

In the globalization era, English becomes the solution to solve the different language 
among the nations. Even, there are some nations use English as their second national language. English is one of the international languages that plays an important role in education, occupation, and government. Indonesia is one of the nations that realized how important is the role of English in this modern era. The government of Indonesia puts English as one of the main subjects in Elementary School until Senior High School. It can be seen by the constitution 2003 number 20 paragraph 33 verse 3 about foreign language. The constitution tells that foreign language can be used as the introduction of language in education aspect to support the ability of the students. This is important to help the citizens ready to face the challenge in ten years ahead.

During the process of language learning at school, there are some problems face by the citizens of Indonesia. These problems cause slow language improvements. Indonesia language is the children's mother tongue. Another problem is because of the different structure in grammar between English and Indonesian. Different sentence structure between English and Indonesia also causes troublesome for students such as lack of confidence to learn and speak in English. They are too afraid to speak English because their grammar is not good.

Those problems exist because English and Indonesian have a different pattern of sentence. The important things to do is to compare two languages to know the differences. The step to compare two languages is doing a contrastive analysis (CA). Contrastive comes from the word "contrast" which has meaning to compare two things so that differences are made clear, showing differences when compared (Hornby, 1974:186). An analysis is separated into parts possibly with comment and judgment, the instance of the result of doing (Hornby, 1974:29). Contrastive analysis is considered as the comparison of the language structure to determine the point that differs them and the sources in learning target language (Lado, 1962:21). Based on the problems stated above, this research will identify and analyze the different sentence structure between English and Indonesia language.

\section{REVIEW OF LITERATURE}

Humans are social beings who have the desire to interact with each other. Humans use thoughts, instincts, feelings, and desires to react and interact with their environment. Social interaction is formed because it is influenced by social action, social contact, and social communication. Language (from Sanskrit भाषा, bhāṣā) is the ability that humans have to communicate with other humans using signs, such as words and movements. The scientific study of language is called linguistics. The number of languages in the world can be estimated between 6,000-7,000 different languages.

According to Keraf in Smarapradhipa (2005: 1), there were two meanings of language. The first definition states language as a means of communication between members of the community in the form of sound symbols produced by human utterances. Second, language is a communication system that uses arbitrary vowel symbols (speech sounds). Another case according to Owen in Stiawan (2006: 1), language can be defined as a socially accepted code or a conventional system to convey concepts through the use of desired symbols and combinations of symbols governed by the provisions. Another definition according to Santoso (1990: 1), language is a series of sounds that are produced consciously by human beings. It can be concluded that a language is a communication tool between members of the community in the form of sound symbols produced by conscious human utterances and the language that we will talk about English and Indonesian Language.

The Indonesian language comes from the Malay language which is used as the official language of the Republic of Indonesia. From a linguistic point of view, Indonesian is one of many 
Malay languages. Although the language is understood and spoken by more than $90 \%$ of Indonesians, Indonesian is not the mother tongue of most speakers. Most of all, the Indonesian might be used one of 748 languages in Indonesia as their mother tongue. Nevertheless, Indonesian is used very widely in educational bench such as college or school, literature, in mass media, official correspondence, software, or various other public forums.

English is a language originally from the United Kingdom. English is a combination of several local languages that are often used by Norwegians, Danes, and Anglo-Saxons. English began to intensely influence Latin as well as French. The total modern English vocabulary, is shown that $\pm 50 \%$ comes from French and Latin. At present, English has become the main communication medium for people in various countries in the world, such as Britain, the United States, Australia, New Zealand, South Africa, Canada, and many more countries.

English as one of the international languages, nowadays becomes one of the very important tools to compete in the next ten years. In facing the industry 4.0, we may also realize and think of competitiveness in finding increasingly tighter work in the next 10 years. We may be lost if we do not realize the world needs this era. Some of us imagine ourselves losing our way because of confusion in balancing the development of the times that are increasingly progressing. Lots of Indonesian people are reluctant to learn English because they thin that learning English takes a longer time. Some other people also said that learning English is boring. Another reason is that English is difficult because there are lots of tenses kinds or even sentences that are very different from Indonesian language.

This study is related to the concept of contrastive analysis. There are various definitions of contrastive analysis which is presented by some experts. According to Guntur Tarigan (1988: 23), contrastive analysis is an activity which tries to compare the structure of L1 and L2 in order to identify the differences between two languages. While Lado (1962:21) introduces contrastive analysis as the comparison of the structures of two languages to determine the point where they differ and the difference is the source of difficulty in learning of target language. From the definition above, it can be concluded that contrastive analysis is an activity in analyzing two differences things. The things that we would like to analyze in this research is the contrastive analysis between English and Indonesian sentence patterns.

There are varieties in one language concerning its purpose. It is classified into five, namely: declarative sentence or declaration, a negative sentence or negation, an interrogative sentence or question, an exclamatory sentence or exclamation, and an imperative sentence or command (Kusumawati, 2009). This research will analyse English and Indonesian differences based on those five sentences.

\section{a. Kinds of Sentences}

\section{1) Declarative Sentence}

A declarative sentence states a fact or arrangement. A declarative sentence ends with a period (.).

Examples:

1. I'll meet you at the train station.

2. The sun rises in the East.

2) Negative Sentence

A negative sentence is a sentence that states that something is negative. In English, we create negative sentences by adding the word 'not' after the auxiliary, or helping, verb. 


\section{Example:}

1. He doesn't get up early.

2. She doesn't write the letter

\section{3) Interrogative Sentence}

The interrogative sentence is sentences that ask a question. The interrogative form ends with a question mark (?).

Examples

1. How long have you lived in France?

2. When does the bus leave?

3. Do you enjoy listening to classical music?

4) Exclamatory Sentence

The exclamatory form emphasizes a statement with an exclamation point (!). Examples:

1. Hurry up!

2. That sounds fantastic!

3. I can't believe you said that!

5) Imperative Sentence

The imperative commands something. The imperative takes subject 'you' as the implied subject. The imperative form ends with either a period (.) or an exclamation point (!).

Examples:

1. Open the door!

2. Stop talking! I'm trying to listen!

3. Pick up that mess.

\section{b. Types of Sentences}

Each sentence can be classified into one of four patterns, which is depending on the number and kind of clauses the sentence contains, as follows:

1) Simple sentences contain no conjunction (i.e., and, but, or, etc.).

Examples:

1. Fred ate his dinner quickly.

2. Are you coming to the party?

3. Pete and Suzy visited the museum last Saturday.

2) Compound sentences contain two statements that are connected by a conjunction Examples:

1. The company had an excellent year, so they gave everyone a bonus.

2. I wanted to come, but it was late.

3. I went shopping, and my wife went to her classes.

3) Complex sentences contain a dependent clause and at least one independent clause. The two clauses are connected by a subordinator.

Examples:

1. That's the man who bought our house.

2. Although it was difficult, the class passed the test with excellent marks.

3. My daughter, who was late for class, arrived shortly after the bell rang.

4) Compound-Complex sentences contain at least one dependent clause and more than one independent clause. The clauses are connected by both conjunctions subordinators Examples:

1. Jerry, who briefly visited last month, won the prize, and he took a short vacation. 
2. Glory forgot his friend's birthday, so he sent him a card when he finally remembered.

3. The report which Mario complied was presented to the board, but it was rejected Because it was too complex.

\section{METHOD}

\section{a. Research Method}

The research method used in this study is a qualitative descriptive method. Qualitative descriptive research is a research procedure that produces data in the form of written words that are descriptions of things. The qualitative descriptive method used in this study is the contrastive analysis between English and Indonesian general sentence. The approach in this research is contrastive analysis. Contrastive analysis in general term is an inductive investigative approach based on the distinctive elements in a language (Kardaleska, 2006). In common definition, the term can be defined as the method of analyzing the structure of any two languages with a view to estimate the differential aspects of their system, irrespective of their genetic affinity of level development (Geethakumary, 2006).

\section{b. Procedure and Data Analysis}

The procedure of this research as systematically below: First, compiling the data or theories supporting this study; books and other materials had a topic related to this writing are examined; Second, analyzing the data obtained followed by the contrasting process between Indonesian and English language, pattern by pattern. Next, providing instrument (15 Indonesian sentences) as representative of the categories. Then, taking data from 20 students of Victory University as samples to translate the sentences (instrument) into English - the target language. Finally, analyzing the students' answers, their translation, and followed by giving a conclusion.

\section{RESULT}

a. Declarative Sentence

\begin{tabular}{|c|c|}
\hline English & Indonesian \\
\hline The sun rises in the East & Matahari terbit dari Timur \\
\hline S V Adverb of Place & $S \quad V \quad$ Adverb of Time \\
\hline $\begin{array}{ccl}\text { You } & \text { speak } & \text { English } \\
\mathrm{S} & \mathrm{V} & \text { Object }\end{array}$ & $\begin{array}{lll}\frac{\text { Kamu }}{S} & \text { bicara } & \text { Bahasa Inggris } \\
V & \text { Object }\end{array}$ \\
\hline$\frac{\text { You }}{\mathrm{S}} \stackrel{\text { were }}{\text { Main.Verb }} \frac{\text { cold }}{\text { Adjectiveective }}$ & $\begin{array}{cl}\text { Kamu } \\
S\end{array} \quad \frac{\text { kedinginan }}{\text { Adjectiveective }}$ \\
\hline
\end{tabular}

In declarative sentences, there are 8 students who translate the sentence based on the pattern whereas 12 students who wrote the wrong verb, which is unacceptable. In other words, the students' answer is mostly incorrect, the students did some errors when choosing the appropriate verb.

b. Negative Sentence

\begin{tabular}{|c|c|}
\hline English & Indonesian \\
\hline$\frac{\text { The sun }}{\mathrm{S}} \frac{\text { does not }}{\text { Negator }} \frac{\text { rise in the East }}{\mathrm{V} \text { Adverb of Place }}$ & $\frac{\text { Matahari }}{\mathrm{S}} \quad \frac{\text { tidak }}{\text { Negator }} \quad \frac{\text { terbit }}{\mathrm{V} \quad \text { Adverb of Place }}$ \\
\hline 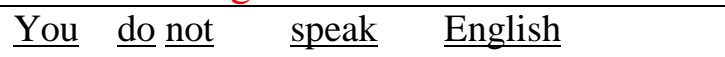 & 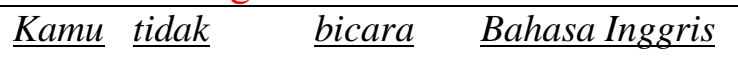 \\
\hline
\end{tabular}




\begin{tabular}{|cc|ccc|}
\hline S & Negator Main Verb Object & $S$ Negator & Main Verb & Object \\
\hline$\underline{\text { You }}$ & $\underline{\text { were not }}$ & $\underline{\text { cold }}$ & Kamu tidak & kedinginan \\
S & Negator & Adjectiveective & $\mathrm{S} \quad$ Negator $\quad$ Adjectiveective \\
\hline
\end{tabular}

In negative sentences, there are 9 students who translate the sentence based on the correct pattern, whereas 11 students who wrote wrong, which is unacceptable. The 5 students wrote the wrong negator and 4 students only wrote "Not" as negator. In other words, generally, the students did some errors especially to choose the appropriate negator.

c. Interrogative Sentence

\begin{tabular}{|c|c|}
\hline English & Indonesian \\
\hline$\frac{\text { When }}{\text { WH-Word }} \stackrel{\text { does }}{\text { Aux.Verb }} \frac{\text { the sun }}{\text { Subject }} \frac{\text { rise? }}{\text { Main Verb }}$ & $\frac{\text { Kapan }}{\text { WH-Word }} \stackrel{\text { matahari }}{\text { Subject }}$ Verbit? \\
\hline $\begin{array}{cccc}\underline{\text { Do }} & \text { you } & \text { speak } & \text { English? } \\
\text { Aux.Verb } & \text { Subject } & \text { Main.Verb } & \text { Object }\end{array}$ & $\begin{array}{llll}\text { Apakah } & \text { kamu } & \text { berbicara } & \text { Bahasa Inggris? } \\
\text { WH-Word } & \text { Subject } & \text { Main.Verb } & \text { Object }\end{array}$ \\
\hline $\begin{array}{ccc}\stackrel{\text { Were }}{\text { Main Verb Be }} & \text { Subject } & \text { cold? } \\
\text { Adjective }\end{array}$ & $\frac{\text { Apakah }}{\text { Main Verb Be }} \quad \begin{array}{ll}\text { kamu } & \text { kedinginan }\end{array}$ \\
\hline
\end{tabular}

In interrogative sentences, there are 6 students who translate the sentence based on the pattern whereas 14 students who did errors. Mostly, the 14 students gave the wrong answers in the last two sentences. They did not write the correct auxiliary verb or main verb be, they only wrote WH-Questions as the question words. In other words, generally, based on the pattern the students' answer is mostly incorrect, the students did some errors especially to choose the appropriate question words.

d. Exclamatory Sentence

\begin{tabular}{|l|l|l|}
\hline \multicolumn{2}{|c|}{ English } & \multicolumn{1}{c|}{ Indonesian } \\
\hline$\underline{\text { What }}$ a $\underline{\text { nice }} \underline{\text { car! }}$ Adjective Noun & $\frac{\text { Mobil yang } \frac{\text { bagus }}{\text { Noun }}}{\text { Adjective }}$ \\
\hline How $\quad \underline{\text { nice! }}$ & $\begin{array}{l}\text { Bagusnya! } \\
\text { Adjective }\end{array}$ & \\
\hline
\end{tabular}

In exclamatory sentences, there are 5 students who translate the sentence based on the pattern whereas 15 students who did errors. Mostly, the 15 students gave the wrong answers. They did not write the correct sentence with the right sentence pattern. For instance, mobil yang bagus they wrote "car nice" or even "car that nice", or bagusnya "nice". They did not put "how/what" to indicate the exclamatory sentence. In other words, generally, based on the pattern the students answer are mostly incorrect.

\section{e. Imperative Sentence}

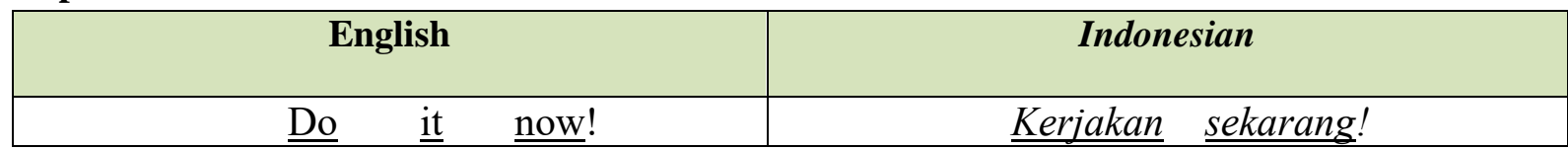




\begin{tabular}{|ccc|ccc|}
\hline Subject(Invisible) & Verb object & Subject(Invisible) & Verb & object \\
\hline Close the door & & $\underline{\text { Tutup }}$ & $\underline{\text { Pintu }}$ \\
Subject(Invisible) & Verb $\quad$ object & Subject(Invisible) & Verb & object \\
\hline
\end{tabular}

In imperative sentences, there are 16 students who translate the sentence based on the pattern, whereas 4 students did errors. Mostly, the 16 students can write sentences with a good pattern. The assumption, because the pattern of English and Bahasa Indonesia sentence pattern is the same "Subject (invisible) + Verb + Object". In other words, generally, the students' answer is mostly correct in the patterns aspect.

Furthermore, to make it clear, the frequency of errors on the sentence pattern of each category from the previous data analysis description is going to be served in the table, as follows:

Table 1. Percentage of Errors on Sentence Pattern

\begin{tabular}{clcc}
\hline No. & \multicolumn{1}{c}{ Category } & Frequency (f) & (\%) \\
\hline 1. & Declarative Sentence (DS) & 12 & 21.43 \\
2. & Negative Sentence (NS) & 11 & 19.65 \\
3. & Interrogative Sentence (IS) & 14 & 25 \\
4. & Exclamatory Sentence (ES) & 15 & 26.78 \\
5. & Imperative Sentence (IMS) & 4 & 7.14 \\
\multicolumn{2}{r}{ TOTAL } & $\mathrm{N}=56$ & $100.00 \%=\sum \mathrm{P}$
\end{tabular}

As we can see from the table and figure of the errors percentage, the main error of the students was in Declarative Sentence (DS), Negative Sentence (NS), Interrogative Sentence (IS) and Exclamatory Sentence (ES) i.e 92.86\%. Based on the research, we found out that the students did those errors because the pattern of those sentences are different whereas the Imperative Sentence (IMS) has the same pattern with English.

\section{CONCLUSION AND SUGGESTION}

The conclusion that can be drawn from the result above is that different sentence pattern between English and Indonesian still becomes a major problem in English language teaching and learning in Indonesia. The students of English Department did not even master all of the sentence patterns in English which is different from Indonesian sentence pattern. The researcher also suggests that English Department has to improve the technique in teaching sentence patterns. The students have to be taught in analyzing the difference of two languages, so they can understand the learning material easily. As long as the students understand the pattern, they will be able to translate easily and use English actively in speaking, listening, writing and reading.

\section{REFERENCES}

Kridalaksana. (1993). Kamus Linguistik: Edisi Ketiga. Jakarta: Gramedia.

Geethakumary, V. (2002). A Contrastive Analysis of Hindi and Malayalam, PhD Dissertation, Language in India, Vol. 2 (Diunduh dari http://repository.um.edu.my/16277/1/LANGUAGE\%20IN\%20INDIA.pdf 3 May 2019) 
Hornby. (1974). Oxford Leaner's Dictionary of Current English. Oxford University Press

Kardaleska, Ljubica. 2006. Contrastive Analysis and Error Analysis in Combination with Analysis of the Semantic Level. Posted on http://www.sil.org. 24 May 2006

Kusumawati, Anita. (2009). Contrastive Analysis Between Indonesian And English Declarative Sentences. English Education Department Faculty Of Tarbiyah And Teachers Training Syarif Hidayatullah State Islamic University. Jakarta.

Lado. (1962). Linguistics Across Culture. Ann Arbor: The University of Michigan Press.

Moleong, Lexy J. (2009). Metode Penelitian Kualitatif. Bandung: Remaja Rosdakarya

Santoso, Kusno Budi. (1990). Problematika Bahasa Indonesia. Bandung: Angkasa.

Smaradhipa, Galih. Bertutur dengan Tulisan. Posted on www.rayakultura.com. 12/05/2005.

Stiawan, Yasin. Perkembangan Bahasa. Posted on www.siaksoft.com. 16/01/2006.

Tarigan, Henry Guntur. (1986). Menulis sebagai Suatu Keterampilan Berbahasa. Bandung: Penerbit Angkasa. 